\title{
Bioformulation Pseudomonas fluorescens SP007s against dirty panicle disease of rice
}

\author{
Sutruedee Prathuangwong ${ }^{1,2 \star}$, Dusit Athinuwat ${ }^{3}$, Wilawan Chuaboon ${ }^{1}$, Tiyakhon Chatnaparat ${ }^{1}$ \\ and Natthiya Buensanteai ${ }^{4}$
}

\author{
${ }^{1}$ Department of Plant Pathology, Faculty of Agriculture, Kasetsart University, Bangkok, 10900 Thailand. \\ ${ }^{2}$ Center for Advanced Studies in Tropical Natural Resources, Kasetsart University, Bangkok, 10900 Thailand. \\ ${ }^{3}$ Major of Organic Farming Management, Faculty of Science and Technology, Thammasat University, Pathumthani, \\ 12121 Thailand. \\ ${ }^{4}$ School of Crop Production Technology, Institute of Agriculture Technology, Suranaree University of Technology, \\ Nakhon Ratchasima, 30000 Thailand.
}

Accepted 8 October, 2013

\begin{abstract}
Two-different carrier formulations, kaolin and talc-based products were developed with Pseudomonas fluorescens SP007s biocontrol agent. SP007s viability in different carriers stored at room temperature (28 to $33^{\circ} \mathrm{C}$ ) slowly declined to approximately 46.2 and $61.0 \%$ after 12-month-old shelf life. The decreased population was first found in five and month months of storage for kaolin and talc-based formulations, respectively. Field experiment with 6-foliar spray intervals $\left(1 \times 10^{8} \mathrm{cfu} / \mathrm{ml}\right)$ of SP007s was conducted against naturally-occurred dirty panicle disease caused by a multiplex fungus at Suphanburi. The two bioformulations significantly reduced pathogen colonization on rice panicle and exhibited the greatest yield that correlated with increased defense-related enzyme accumulation in treated plants, compared to 4-fungicide spray intervals and nontreated control. Protection of seeds collected from colonized and noncolonized plants of dirty panicle treated with bioformulations $\left(1 \times 10^{6} \mathrm{cfu} / \mathrm{ml}\right)$ and fungicides (copper hydroxide) was further determined for 12 months of storage at room temperature. The best results in reducing 6-causal fungi including Alternaria padwickii, Cercospora oryzae, Curvularia lunata, Fusarium semitectum, Helminthosporium oryzaeqe and Sarocladium oryzae; and induced seedling vigor (35\%) were obtained from SP007s kaolin-based formulation evaluated at 8-month storage, but not at 12 months which indicated that these causal pathogens totally recovered their colonization except S. oryzae. In 8-month trials, control efficacy with dose of $1 \times 10^{6} \mathrm{cfu} / \mathrm{ml} \mathrm{SP007s} \mathrm{seed}$ treatment, the increase in SP007s populations relatively with the decreased colonization of pathogens could be found. SP007s in kaolin-based formulation increased GABA in SP007s treated seeds suggesting this plant bioactivator may involve plant's defense against stress conditions also.
\end{abstract}

Key words: Biocontrol, multiplex fungus causes, induced systemic resistance, protective enzymes, reduced chemical application.

\section{INTRODUCTION}

Dirty panicle of rice (Oryza sativa L.), one of the most

important diseases in Thailand can cause great losses in 
grain and seed production which makes it unacceptable for consumption and seeding. The disease caused by multiplex fungi includes Alternaria padwickii, Cercospora oryzae, Curvularia lunata, Fusarium semitectum, Helminthosporium oryzae and Sarocladium oryzae. They favor to infect plants at panicle forming stage under high temperature $\left(28\right.$ to $\left.33^{\circ} \mathrm{C}\right)$ and humidity $(>80 \% \mathrm{RH})$. Some of these causal fungi also cause leaf spot or blight of rice, but the most destructiveness was found when they attack the panicle, kill the seed or exhibit seed borne infestation (Department of Agriculture, 2011) that may remain active during storage, transport and marketing. If the temperature is higher than $28^{\circ} \mathrm{C}$, all causes of fungi spread rapidly from the infected to adjacent seeds. Use of contaminated seeds for planting may favor the increase in disease incidence. There are no adequate control measures to manage the disease if predisposing factors such as susceptible cultivars and weather conditions mentioned earlier are favorable for disease development. Biological control of plant pathogen is becoming an important component of plant disease management practices. This alternative control strategy can solve many persistent problems in agriculture including fungicide residues causing environmental pollution and human health hazard, and also inducing pathogen resistance (Commare et al., 2002; Cook, 2002; Bharathi et al., 2004; Chaluvaraju et al., 2004; Anitha and Rabeeth, 2009; Chen et al., 2009; Ardakani et al., 2010, 2011; Haggag and Wafaa, 2012).

The use of plant growth promoting rhizobacteria (PGPR) isolated from cauliflower root, Pseudomonas fluorescens SP007s as biocontrol agent in protecting various plants from several diseases caused by bacteria and fungi have been reported for multiple studies (Chuaboon et al., 2009; Prathuangwong, 2009); but not yet for dirty panicle of rice. Biocontrol mechanism by this PGPR strain SP007s revealed antibiosis; production of siderophore, auxin, and gibberellins; and inducing systemic resistance of plants (Prathuangwong et al., 2009). The phenomenon called induced systemic resistance (ISR) regulates through the activation of multiple defense compounds at sites distance from the point of pathogen attack (Prathuangwong and Buensanteai, 2007; Buensanteai et al., 2008). The inducers include pathogens, PGPR, chemicals and plant extracts (Buensanteai et al., 2009).

ISR by PGPR typically do not cause any necrotic symptoms on the host that is an activation of latent resistant mechanisms. Following applied of an inducer to plant, defense mechanisms may be triggered directly or they may be triggered only once pathogen challenges inoculations (Buensanteai et al., 2009). The defense responses activated include hypersensitive response $(\mathrm{HR})$ leading to cell death and synthesis of antimicrobial compounds such as phyto-alexins and pathogenesisrelated proteins (PR-proteins).

Except these defensive compounds, role in plants of GABA ( $\gamma$-aminobutyric acid), a nonprotein amino acid functions in animal as a major inhibitory neurotransmitter (Erlander and Tobin, 1991) detected in nongerminated and germinated rice may also involve in plant's defense against biotic stress (Ramputh and Bown, 1996). The strains of PGPR, the major root colonizers are known to survive both in the rhizosphere, spermosphere and phyllosphere diverse that can be resident in environments (Cook, 2002). They stimulate plant growth by improving plant nutrition (Buensanteai et al., 2008), releasing plant growth regulations (Buensanteai et al., 2009), and by inhibiting plant pathogens (Van Loon et al., 1998; Chuaboon and Prathuangwong, 2007; Prathuangwong and Buensanteai, 2007; Buensanteai et al., 2009; Prathuangwong, 2009; Prathuangwong et al., 2009). These benefit bacteria can be a significant component of management practices to achieve the attainable yield.

The use of PGPR strains as biocontrol agents against dirty panicle of rice has not widely been reported although biological control of rice diseases has recently been investigated (Prathuangwong et al., 2008). The implementation of formulating biocontrol agent particular crop systems with greenhouse or field crops and seed treatment or seed coating using PGPR appears to be feasible method for dirty panicle disease (Prathuangwong et al., 2008). A formulated product must be economical to produce, easy to apply in the crop production system, efficacies with an adequate number of viable cells when used, and a shelf-stable formulated product retraining biocontrol activity comparable to fresh cells of the agent.

Delivery systems employing biocontrol agent include dust or powder, alginate pellet, and starch or extruded granule that the effective strains are necessary to be grown in various organic and inert carries, such as diatomaceous earth, manure or animal dung (Raj et al., 2003; Schisler et al., 2004; Sharathchandra et al., 2004; Amran, 2006; Pushpalatha et al., 2007; Preecha and Prathuangwong, 2009; Omer, 2010; Senthilraja et al., 2010; Siripornvisal and Trilux, 2011). Understanding of colonization ability, mechanisms of action, formulation and application should facilitate their development as reliable component in the management of sustainable agriculture system.

The objectives of this study were to evaluate: i) the efficacy of $P$. fluorescens SP007s in two formulations for control of dirty panicle, ii) viability and biocontrol efficacy after storage time, iii) spermosphere colonization of SP007s and causal pathogens, iv) formulation efficacy for control of field crop and storage seeds, and v) plant response induced by SP007s. 
Table 1. Summary of product and treatment used in the experiments.

\begin{tabular}{ll}
\hline Treatment code $^{\mathbf{1}}$ & Treatment detail \\
\hline T1 & $\begin{array}{l}\text { 6-foliar sprays }\left(20 \mathrm{~g} / 20 \mathrm{~L} \mathrm{H}_{2} \mathrm{O}\right) \text { at } 20,30,40,50,60 \text { and } 70 \text { days after planting with kaolin-based powder } \\
\left.\text { product (approximate } 1 \times 10^{8} \mathrm{cfu} / \mathrm{ml}\right) .\end{array}$ \\
T2 & $\begin{array}{l}\text { Dose and application were same as } \mathrm{T} 1, \text { but with talc-based powder product. } \\
\text { 4-foliar sprays at } 28,42,56, \text { and } 70 \text { days after planting with fungicides propiconazole, copper hydroxide }\end{array}$ \\
T3 & Nontreated control. \\
T4 &
\end{tabular}

\section{MATERIALS AND METHODS}

\section{Formulations of $P$. fluorescens SP007s}

The PGPR strain SP007s obtained from the Department of Plant Pathology, Kasetsart University, Thailand that isolated from cauliflower rhizoshere (Prathuangwong, 2009) was cultured in flasks on rotary incubator shaker at room temperature $\left(28\right.$ to $\left.33^{\circ} \mathrm{C}\right)$ for $48 \mathrm{~h}$. Antagonistic activity of SP007s was tested against Xanthomonas oryzae pv. oryzae a cause of bacterial leaf blight of rice using a standard dual culture technique by parallel streaked the two strains onto nutrient glucose agar plates prior to further study.

To prepare biomass of SP007s cells, fermented broth was concentrated in a refrigerated and high-speed centrifuge $(10,000$ rpm), cells of SP007s were formulated using patent technology developed by Prathuangwong (2009) patent submission: "ISR-P", code number (0901001791) for the stabilization of $P$. fluorescens SP007s. Briefly, the inert material preparation was developed with talc; and kaolin-based powders contained talc-based: glucose : China clay: $\mathrm{CMC} \mathrm{CaCO}_{3}: \mathrm{FeSO}_{4}$ with $34: 29: 34: 1: 1: 1$; and kaolin : deshefix : $\mathrm{SiO}_{2}: \mathrm{CaCO}_{3}$ : lactose : $\mathrm{CMC}: \mathrm{FeSO}_{4}$ with $70: 8$ $: 1: 5: 14: 1: 1$ ratios, respectively.

The individual mixtures was moistened $5 \% \mathrm{H}_{2} \mathrm{O}$ to form workable dough and sterilized in an autoclave at $121^{\circ} \mathrm{C}$ for $15 \mathrm{~min}$. Powder was then dried in a laminar air flow cabinet overnight prior to use in the formulation process.

Colony forming unit (cfu) of SP007s growth in sterile phosphate buffer (PBS) was determined by estimating the optical density of the bacterial suspension using spectrophotometer (CECIL 1011) adjusted to 1.2 (approximately $1 \times 10^{13} \mathrm{cfu} / \mathrm{ml}$ ) at $600 \mathrm{~nm}$ absorbance wavelength. The bacterial suspension was gently sprayed on talc- and kaolin-based powders at ratio 1 (biomass): 99 (other mixed ingredients aforementioned). The products were shade dried overnight to reduce the moisture content below $3 \% \mathrm{RH}$ in a laminar flow hood.

Dried formulations were packed in sealed aluminum foiled bags ( $1 \mathrm{~kg}$ each) and stored at room temperature prior to use. To estimate number of viable cells, the standard dilution plating method with 1 to 9 aliquots of the dried powders from each formulation placed in solution of PBS plus $0.01 \% \mathrm{v} / \mathrm{v}$ Tension-7 and stirred for $10 \mathrm{~min}$ was conducted. The suspended dilutions were made and $0.2 \mathrm{ml}$ aliquots plated on King's medium B. Total SP007s populations in 1 to 9 aliquots of talc and kaolin-based powders needed from mean counts of $1 \times 10^{13} \mathrm{cfu} / \mathrm{g}$ on the day of preparing the formulations. The shelf-life of SP007s formulations stored at room temperature was determined at monthly interval throughout 12-month storage. The viable cells in each formulation were evaluated by counting cfu using standard dilution plating as aforementioned.

\section{Effect of foliar spray with bioformulation under field experiment}

Each formulation of SP007s strain was tested in farmer's field at Thongkock, Suphanburi with 3 replications of a completely randomized design arrangement. Plot size of $400 \times 400 \mathrm{~m}^{2}$ was maintained for all treatments. Rice seeds cv. Phitsanulok 60 were initially grown as conventional broadcast seeding with $125 \mathrm{~kg}$ seeds $\mathrm{ha}^{-1}$. The powder product of 6-month-old shelf life (approximate 125 $\left.\mathrm{g} \mathrm{ha}^{-1}\right)$ mixed in water $\left(20 \mathrm{~g} \mathrm{~L}^{-1}\right)$ for foliar spray $\left(1 \times 10^{8} \mathrm{cfu} / \mathrm{ml}\right)$ until run-off using knapsack sprayer was conducted at 10-day intervals on rice plants prior to the expected infection for dirty panicle attack (the panicle formation stage) begun from 20 to 70 -day-old plants (total 6-sprays). The chemical fungicides (propiconazole, difenoconazole, and copper hydroxide) at 2-week interval (begun from 28-day-old for total 4 sprays) and untreated control were maintained. No any foliar spray was done after 70-day-old plant at panicle and/or early seed formed stage. Different formulations and treatments were listed in Table 1. Panicles and/or seeds randomly selected at the panicle stage were picked intervals for evaluating natural infection by dirty panicle. Seed or grain yield was recorded at the time of harvest for all treatments. Changes of defense-related enzymes were also measured intervals at 1 day after SP007s spray and also every week after the last spray until harvest. Protein and enzyme assay following plant response investigation were later described.

\section{Effect of seed treatment with bioformulation under storage conditions}

The experiment was carried out to test the effectiveness of seed treatment with two-powder formulations of $P$. fluorescens SP007s under storage conditions of 28 to $33^{\circ} \mathrm{C}$ and kept in a closed plastic bag placed on a laboratory bench at Department of Plant Pathology, Kasetsart University, Bangkok. Seeds collected from healthy (symptomless) and infected panicles were washed in sterile distilled water and dressed with dried powder formulation of strain SP007s (10 month-old-shelf-life) with approximately $100 \mathrm{~g} \mathrm{seeds} / 0.1 \mathrm{~g}$ 
bioformulation (approximately $1 \times 10^{6} \mathrm{cfu} / \mathrm{ml} \mathrm{SP007s).} \mathrm{The} \mathrm{entire}$ mixture was shaker in a plastic bag for 2 to $3 \mathrm{~min}$ to form an even coating of the seeds, copper hydroxide and nontreated seeds were served as control treatments. All set of seeds were dried under a laminar airflow cabinet before storage in a plastic bag at room temperature. Treatments consisted of 5 replications of 1,500 seeds each. To estimate incidence of recovery and population size of SP007s and causal pathogens on storage seeds, 100 seeds were sampled monthly from each treatment. Two-separated set were evaluated with seed-washed dilutions and seeding onto solid media. Seeds were suspended in PBS buffer, sonicated, vortexed, and the dilutions were spreaded on King's medium $B$ under amended with $150 \mu \mathrm{g} / \mathrm{ml}$ amplicilin and $150 \mu \mathrm{g} / \mathrm{ml}$ rifampicin (Nurapak and Prathuangwong, 2010); and V-8 juice agar for detection of $P$. fluorescens SP007s; and dirty panicle pathogens, respectively.

For double check, seeds were washed with PBS, subjected to slow air drying, and placed on two media above ( 25 seeds/plate). The plates were incubated in the growth cabinet and the cfu and colonization were recorded. In another set, treated seeds were determined for seedling vigor by agar plate method and GABA accumulation in germinated seeds was analyzed using the following procedure described:

\section{Plant's defense response by SP007s formulations}

Assay of defense-related proteins and enzymes were investigated. One gram $(1 \mathrm{~g})$ leaf of each treatment sampled intervals at 1 day after SP007s foliar spray and every week after the last spray until harvest was homogenized with $2 \mathrm{ml}$ of $0.1 \mathrm{M}$ sodium citrate buffer $\left(\mathrm{pH} \mathrm{5.0)}\right.$ at $4^{\circ} \mathrm{C}$. The homogenate was centrifuge for $20 \mathrm{~min}$ at $10000 \mathrm{rpm}$. The supernatant was used as crude enzyme extract for assaying $\beta$-1,3-glucanase ( $P a n$ et al., 1991), guaiacol peroxidaseGPX (Upadhyaya et al., 1985), peroxidase-POX (Hammerschmidt et al., 1984), phenylalanine ammonia-lyase-PAL (Prathuangwong and Buensanteai, 2007) and superoxide dismutase-SOD (Dhindsa et al., 1981). Enzyme extract was stored at $-80^{\circ} \mathrm{C}$ until used for biochemical analysis. Protein content in the extract was determined by the method of Bradford (1976) with minor modification. Briefly, Bradford reagent was added to $0.1 \mathrm{ml}$ of extract and absorbance of the mixture was read at $595 \mathrm{~nm}$ after a reaction time of $2 \mathrm{~min}$. Sample protein content was determined from a standard curved generated with bovin serum albumin (Buensanteai et al., 2009). Analysis of GABA was extracted using the procedures described by Cohen et al. (1994), Ling et al. (1994) and Ming et al. (2011) with minor modification.

The seed-ground samples were thawed in $500 \mu \mathrm{l}$ of a mixture of methanol: chloroform: water 12:5:3 (v/v/v). The mixture was vortexed and centrifuged at $13,000 \mathrm{rpm}$ at $4^{\circ} \mathrm{C}$ for $15 \mathrm{~min}$. The supernatant was collected, $200 \mu \mathrm{l}$ chloroform and $400 \mu \mathrm{l}$ water were added to the pellet. The resulting mixture was vortexed and centrifuged for $15 \mathrm{~min}$ at $13,000 \mathrm{rpm}$. The supernatant was collected and combined with the first supernatant and recentrifuge to collect the upper phase. The collected samples were dried in a freeze-dryer and redissolved in water. The resulting contained GABA and other amino acid. Each sample was characterized by HPLC analysis (Ming et al., 2011).

\section{Statistical analyses}

The experiments were analyzed using SPSS version 15. Data on growth, disease incidence, yield, population size of SP007s and pathogens colonized on seeds were subject to analysis of variance
(ANOVA). The treatment means were compared by Duncan's multiple rage tests (Levesque, 2007).

\section{RESULTS}

\section{Property of SP007s formulations}

At each month of sampling, the average powder dissolution or viscosity and suspension of SP007s in kaolin-based formulation were significantly better than in talc-based formulation in that the kaolin-based compound tended to dissolve faster in water. No significant fitness of SP007s by these 2-formulations on rice leaves was observed at 1 day after foliar spray. However, SP007s populations were lower on the leaf surface than in the bioproducts, except for $6^{\text {th }}$-month sampling date that numerous SP007s cfu were recovered. In both talc and kaolin-based products, the average culturable populations of SP007s detected from rice plants were 2-fold higher than the source bioproducts at the date of plant harvest suggesting potential adaptation and residence by SP007s (data not shown). The use of different gradients in bioproducts tested appears to determine the proportion of the total bacterial population that was culturable. Aggregation of bacterial cells could be a cause for lower culturable population. However, extensive aggregation as indicated by suspension property of powder product mentioned earlier was not evident when observed sample for active cell enumeration. The bioproduct must be quickly dissolved in water in order to activate its bacterial activity and eliciting properties that kaolin-based powder formulation dissolved in water is a faster alternative compared to talc-based.

Viability of strain SP007s cells in talc and kaolin-based formulations were estimated as a mean number of cultural colonies every month during 12 months of storage at room temperature. This biocontrol agent survived up to four and five months without any dramatic decline from the initial population (Figure 1). Although, subsequently, there was a slight decline in the population, four and five months after storage that was same $1 \times 10^{12}$ $\mathrm{cfu} / \mathrm{ml}$ obtained from both talc and kaolin based formulations. A reduction to 53.8 and $46.3 \%$ viability of SP007s was found in talc and kaolin-based formulations at 12 months of storage respectively, compared to the initial density (Figure 1).

\section{Efficacy of $\boldsymbol{P}$. fluorescens SP007s in field experiment}

The $P$. fluorescens strain SP007s in both formulations kaolin and talc-based (T1 and T2) significantly reduced the percentage incidence of dirty panicle; and increased rice yield compared to fungicide spray in T3, although the last spray at 70-day-old plant with either SP007s bioproducts 


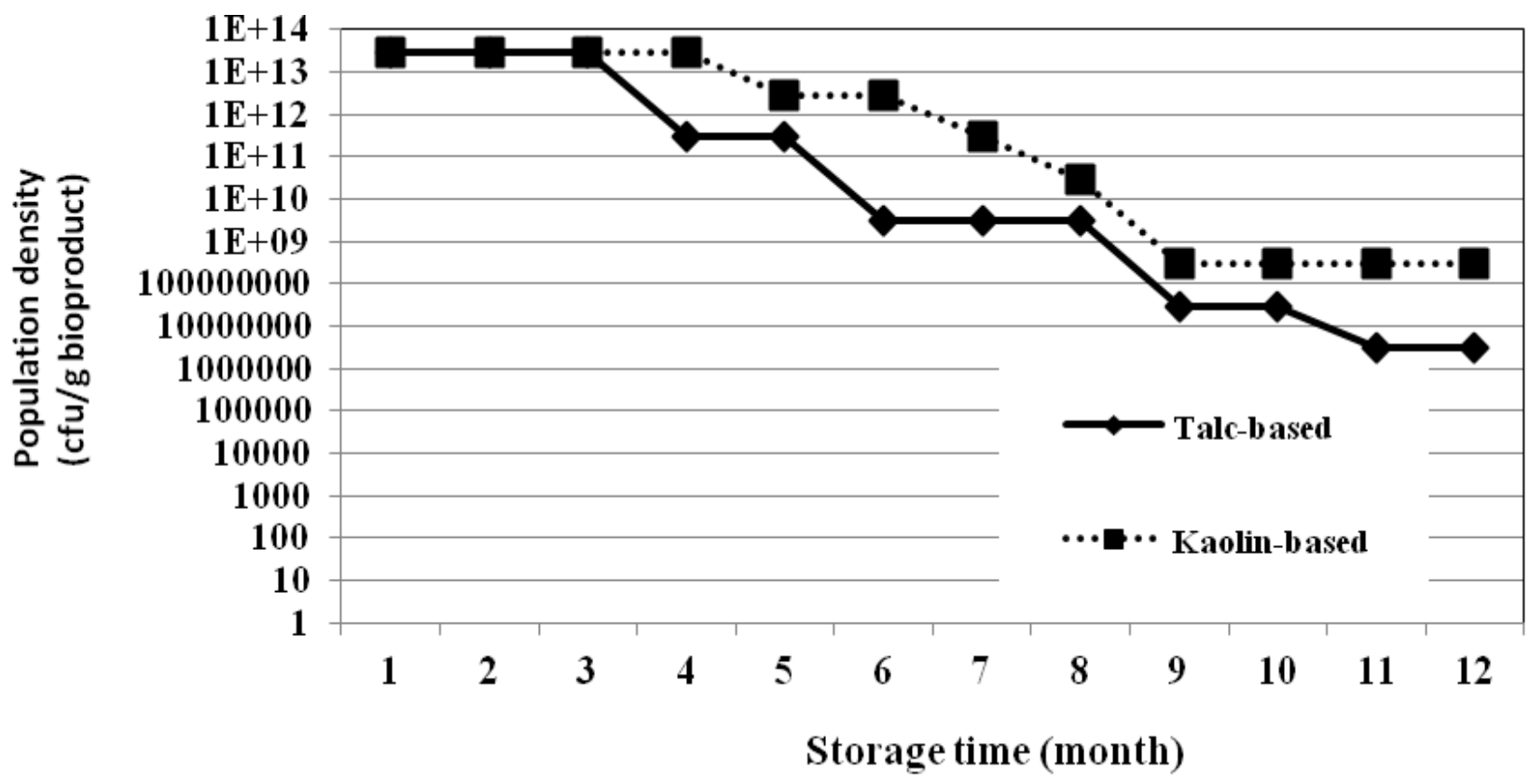

Figure 1. Survival of Pseudomonas fluorescens SP007s in talc and kaolin-based formulations during 12 months of storage at room temperature.

Table 2. Efficacy of Pseudomonas fluorescens SP007s bioformulation on disease reduction of dirty panicle and increase in yield and defense-related enzymes of rice plants under field experiment ${ }^{1 /}$.

\begin{tabular}{|c|c|c|c|c|c|c|c|c|c|c|}
\hline \multirow{3}{*}{ Treatment $^{2 /}$} & \multirow{2}{*}{\multicolumn{4}{|c|}{$\begin{array}{c}\text { Disease reduction }(\%)^{3 /} \\
\text { Day-old-plant evaluation }\end{array}$}} & \multirow{2}{*}{\multicolumn{5}{|c|}{ Accumulation of defense related enzyme $e^{4 /}$}} & \multirow{3}{*}{ Yield (ton/ha) } \\
\hline & & & & & & & & & & \\
\hline & 77 & 84 & 91 & 98 & GPX & $\beta-1,3$ & PAL & POX & SOD & \\
\hline $\mathrm{T} 1$ & $72.3^{b}$ & $7.2^{b}$ & $20.0^{\mathrm{b}}$ & $44.9^{\mathrm{a}}$ & $0.9^{\mathrm{a}}$ & $3.0^{\mathrm{a}}$ & $8.5^{\mathrm{a}}$ & $1.4^{\mathrm{a}}$ & $2.6^{\mathrm{b}}$ & $7.3^{\mathrm{a}}$ \\
\hline T2 & $78.7^{\mathrm{a}}$ & $22.9^{\mathrm{a}}$ & $33.3^{\mathrm{a}}$ & $38.0^{\mathrm{a}}$ & $0.9^{\mathrm{a}}$ & $2.6^{\mathrm{b}}$ & $8.0^{\mathrm{a}}$ & $1.0^{\mathrm{b}}$ & $3.0^{\mathrm{a}}$ & $7.3^{\mathrm{a}}$ \\
\hline T3 & $72.3^{\mathrm{b}}$ & $0^{c}$ & $0^{c}$ & $8.7^{\mathrm{b}}$ & $0.9^{\mathrm{a}}$ & $2.6^{\mathrm{b}}$ & $8.2^{\mathrm{a}}$ & $0.9^{\mathrm{b}}$ & $2.0^{\mathrm{c}}$ & $4.8^{\mathrm{b}}$ \\
\hline T4 & $0^{c}$ & $0^{c}$ & $0^{c}$ & $0^{c}$ & $0.8^{\mathrm{a}}$ & $2.0^{c}$ & $5.0^{b}$ & $0.6^{c}$ & $1.1^{d}$ & $2.1^{\mathrm{c}}$ \\
\hline CV & 66.9 & 143.5 & 122.5 & 95.6 & 12.8 & 16.3 & 21.8 & 33.7 & 20.6 & 46.2 \\
\hline
\end{tabular}

$\frac{1}{2}$ Means followed by same letter in a column are not significantly different according to Duncan's multiple range test $(P=0.05)$.

$2 /$ Details of treatments (T1 to T4) are same as listed in Table 1.

$3 /$ Treatment T1 to T3 were compared with nontreated control T4 that T3 revealed severe colonization at 84 and 91 -day old plant.

4/ Average from 10-time-evaluation, GPX = guaiacol peroxidase (unit $\mathrm{mg}^{-1}$ protein), $\beta-1,3=\beta-1,3-$ glucanase $^{-1}$ unit $\mathrm{mg}^{-1} \mathrm{protein}^{-}$, $\mathrm{PAL}=\mathrm{phenylalanine}^{-1}$

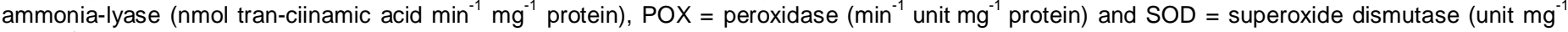
protein).

or fungicides was conducted (Table 2). Overall reduction of dirty panicle by SP007s ranged between 7.2 to $78.7 \%$ depending on the different formulations used and plant ages determined that the disease symptom was firstly found 1 week after last spray (Table 2).

Fungicide treat-ment was slightly less effective in controlling this disease that dirty panicle increased development with incidence percentages in nontreated control (data not shown). Assay of defense enzymes revealed that SP007s bioformulation induced a greater amount of enzymes in the SP007s-treated plants than the fungicide or nontreated control, although only one to two- fold increase in accumulation among GPX, $\beta$ 1,3-glucnase, PAL, POX and SOD were detected in rice plant treated with $P$. fluorescens SP007s for 6-foliar spray intervals (Table 2). At plant growth stage formed for pathogen infection (70 to 98-day-old plants), no spray was carried out suggesting that SP007s mediated systemic resistance induction might be correlated with disease reduction. 


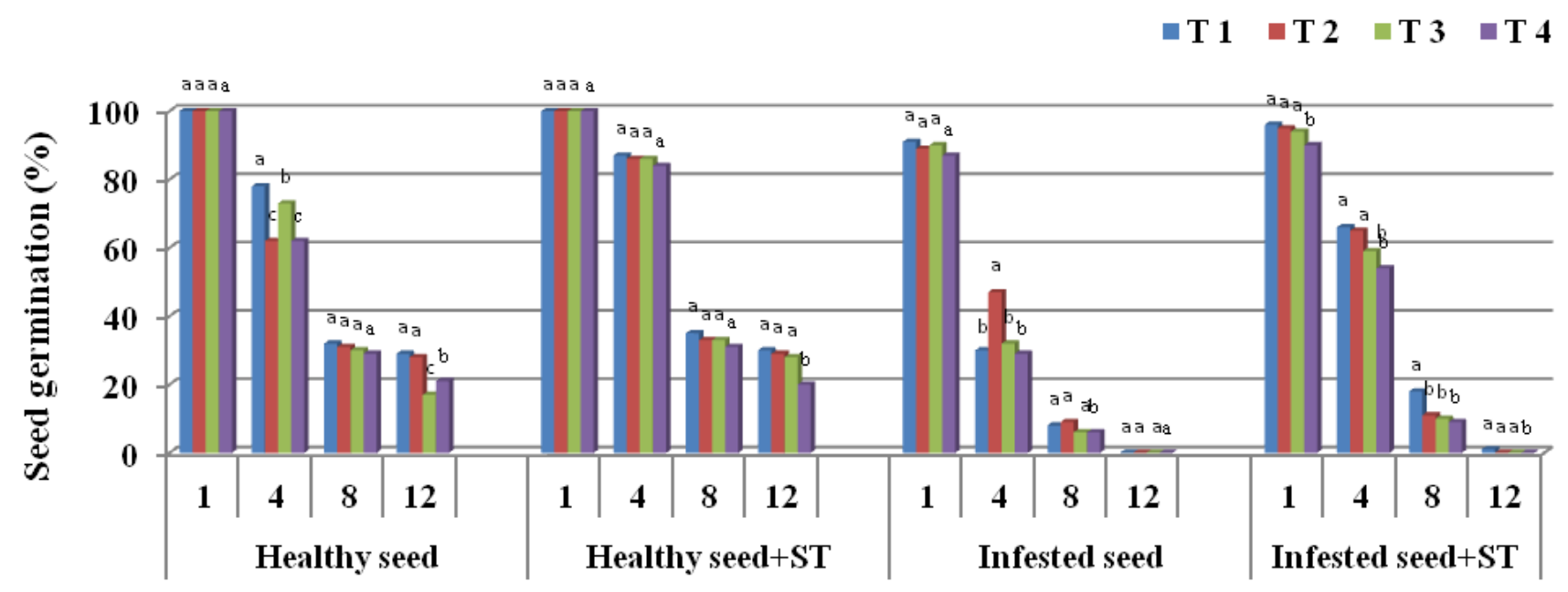

\section{Time after seed stor age (month)}

Figure 2. Seed germination of treated seeds (ST) with different products of T1 to T4 (healthy seed + ST and infested seed + ST) and nontreated control (healthy and infested seeds) evaluated monthly interval during 12-month-storage. Details of T1 to T4 are same as listed in Table 1. Letters labeling bars indicate significantly different percentage of seed germination, and treatments with the same letter are not significantly different $(P=0.05$ according to Duncan's multiple rang test).

\section{Seed treatment evaluation}

The efficacy of the two formulations of $P$. fluorescens SP007s tale and kaolin-based powder products on seed germination and seedling vigor are presented in Figures 2 and 3 , respectively. Percentage of seed germination obtained from treated seeds with SP007s was higher than nontreated control in either symptomless or infested seeds suggesting that $P$. fluorescens SP007s protects seeds from pathogen attack and promotes growth enhancement of rice seedlings. Noninfested or healthy and infested seeds of rice treated with $10^{6} \mathrm{cfu} / \mathrm{ml} \mathrm{SP007s}$ bioformulations ( $\mathrm{T} 1$ and $\mathrm{T} 2$ ) showed improvement in seedling growth parameters over fungicide and untreated seeds. SP007s was found to significantly increase the vigor index of rice seedlings. The increase in main root length $(9.9 \mathrm{~cm})$ and shoot height $(46.1 \mathrm{~cm})$ including fresh $(106.2 \mathrm{~g})$ and dry weight $(16.5 \mathrm{~g})$ due to SP007s was significantly higher in $\mathrm{T} 1$ and $\mathrm{T} 2$ compared to the seedlings from T3 and T4 (Figure 3). The greatest vigor index of 43.8 was observed in the seedling treated with kaolin-based formulation containing SP007s strain (Figure 3). The positive colonization ability of SP007s as the successful colonizer of the spermosphere and its establishment on rice seeds (Figure 4) and increased seedling emergence (Figure 2) resulting in enhanced seedling vigor (Figure 3 ) was recorded. The relative number of 6 -fungal pathogens (A. padwickii, C. oryzae, C. lunata, F. semitectum, $H$. oryzae and $S$. oryzae) in each seed treatment represented the relative population sizes of $P$. fluorescens SP007s on seeds. Quantitative differences were observed between common spermosphere and colonizer that epiphyte of SP007s was much greater than that of pathogen colonization at the $4^{\text {th }}$ month of seed storage in that $S$. oryzae was completely eliminated (Figure 4). The pathogen as a colonizer was diversity greater with increase time of storage demonstrating that one time initial treatment of seeds with strain SP007s in tale-based formulation may be not sufficient to suppress these colonized pathogens throughout a longer incubation. Heavy infested seeds are also affected a success of protection with seed coating assay.

In this study, strain SP007s in kaolin-based formulation (T1) showed the best result in suppressing all 6seedborne pathogens throughout 12-month incubation (Figure 4), resulting highestly increased seedling vigor (Figure 3) and GABA accumulation (Figure 5). Seed treatment with copper hydroxide in T3 demonstrated equivalent or less inhibition against spermosphere pathogens after 4 months but not at 8 or 12 months of storage, compared to T1 and T2 (Figure 4). However, colonization of seeds with different pathogens in nontreated control T4 was one-fold increase from the original population after 12-month storage at room temperature (Figure 4). Strain SP007s colonized and grew rapidly on treated seeds. The population levels of SP007s at $1 \times 10^{13} \mathrm{cfu} / \mathrm{g}$ of seed within three month after treatment were obtained. This population levels decrease during the following four months of storage. No significant 


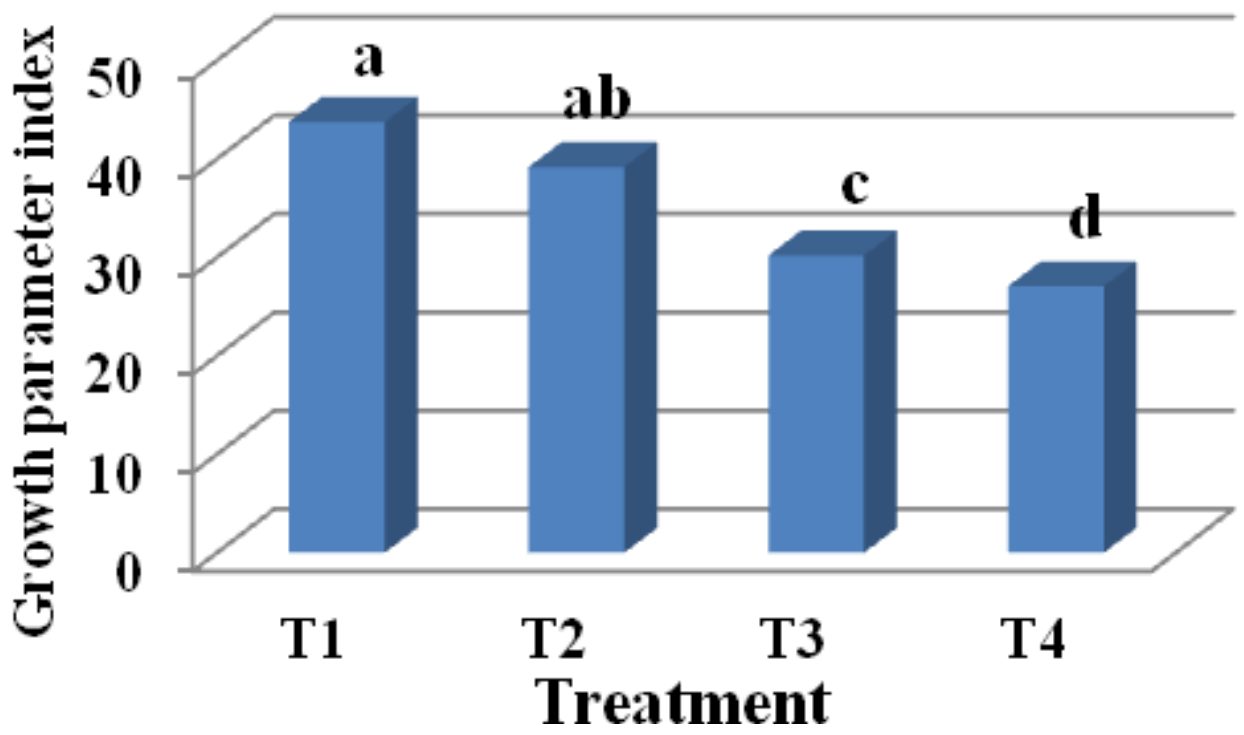

Figure 3. Effect of Pseudomonas fluorescens SP007s bioproducts treated infested seeds on seedling vigor of rice as shown by growth parameter index (plant growth index = root length + plant height + plant fresh weight + plant dry weight/4). Details of T1 to T4 are same as listed in Table 1. Bars with the same letters are not significantly different $(P=0.05$, Duncan's multiple range test).

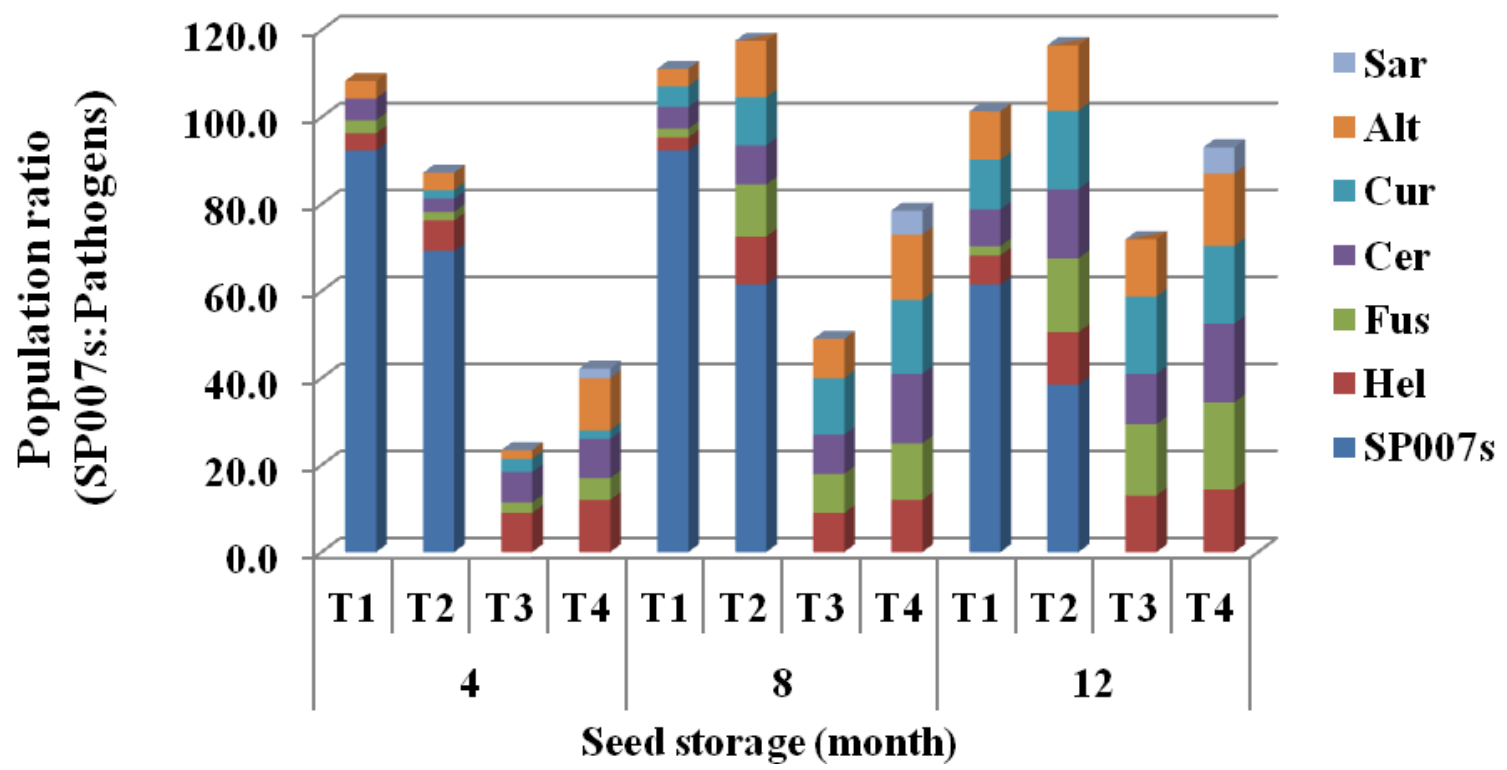

Figure 4. Effect of bioproduct seed treatment on population level of biocontrol agent Pseudomonas fluorescens SP007s and pathogen colonization. Hel = Helminthosporium, Fus = Fusarium, Cer = Cercospora, Cur = Curvularia, Alt $=$ Alternaria and Sar $=$ Sarocladium . Details of T1 to T4 are same as listed in Table 1.

differences in population levels were observed among the initial concentration inoculated $\left(1 \times 10^{6} \mathrm{cfu} / \mathrm{ml}\right)$ except for T2 which attained levels of only $1 \times 10^{5} \mathrm{cfu} / \mathrm{g}$ seed after 12-month incubation. GABA was extracted from symp- tomless and infested seeds treated with SP007s that allowed seed germinated overnight before analysis. Change of GABA concentration in germinated seeds is shown in Figure 5. All seed treatments with T1 to T3 (SP007s 


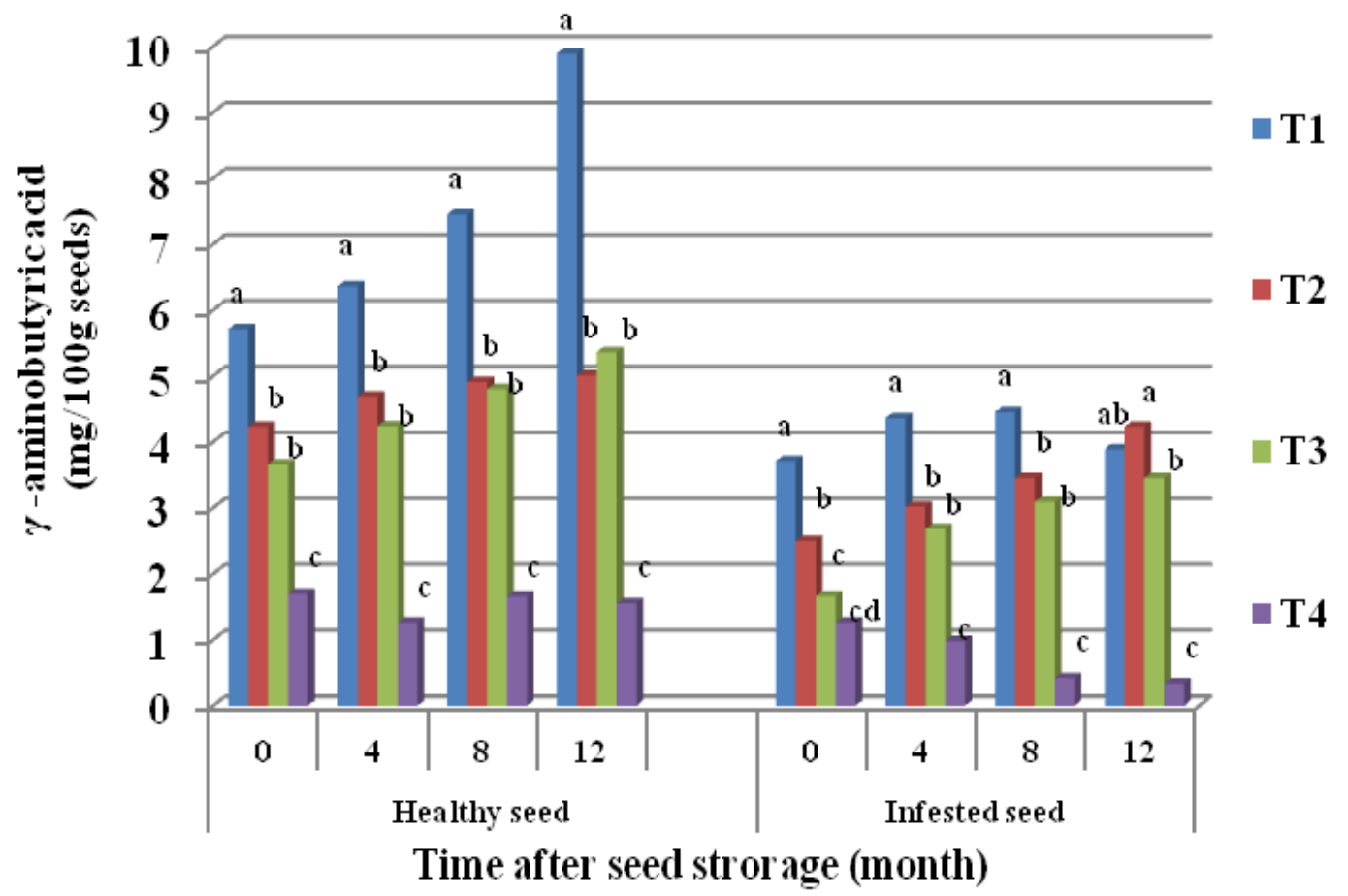

Figure 5. Increased GABA concentration in rice seeds treated with $P$. fluorescens SP007s detected during overnight germination. T1 to T4 are same as listed in Table 1. Bars with the same letters are not significantly different $(P=0.05$, Duncan's multiple range test).

kaolin, SP007s talc-based formulation and copper hydroxide) significantly enhanced GABA accumulation compared to nontreated control in T4. The symptomless seeds increased higher GABA than the infestation after they were treated with SP007s. The highest GABA increase was however, found in symptomless seeds treated with SP007s kaolin-based formulation, which was 4.7 and 3.1-fold higher than nontreatment of symptomless and infected seeds respectively (Figure 5).

The data obtained clearly showed that the concentration of GABA significantly increased by rice seeds treated with $P$. fluorescens SP007s strain, and GABA concentration decreased in seeds infested with multiplex pathogens was observed. GABA was postulated to have a role in nitrogen storage and growth metabolism in plants that resulted in disease resistance by inducing PRproteins such as $\beta-1,3-$ glucanase and chitinase.

\section{DISCUSSION}

The efficacy of plant growth promoting rhizobacteria in plant pathogen inhibition, growth promotion and resistance induction in various economic crops is well understood (Commare et al., 2002; Cook, 2002; Raj et al., 2003; Bharathi et al., 2004; Chaluvaraju et al., 2004; Chuaboon and Prathuangwong, 2007; Prathuangwong and Buensanteai, 2007; Buensanteai et al., 2008; Anitha and Rabecth, 2009; Chen et al., 2009; Chuaboon et al., 2009; Ardakani et al., 2010, 2011; Haggag and Wafaa, 2012).

The results reveal in this study corroborate earlier studies and indicate a future possibility that plant growth promoting rhizobacteria bioformulations can be used to promote growth and health of economic crops (Raj et al., 2003; Chuaboon and Prathuangwong, 2007). Seed treatment and foliar application with plant growth promoting rhizobacteria bioformulations significantly en-hanced the growth of rice plants and particularly reduced the percentage of dirty particle disease incidence and severity.

Our results suggest that, the $P$. fluorescens strain SP007s in both formulations kaolin and talc-based significantly reduced the percentage incidence of dirty panicle; and increased rice yield compared to fungicide spray. In the previous study, strain SP007s survived in ISR-P ${ }^{\circledR}$ product up to 18 months of storage with $46.2 \%$ viability reduction has been reported (Chuaboon and Prathuangwong, 2007). However, with respect to the inoculum dose applied $1 \times 10^{6}$ and $1 \times 10^{8} \mathrm{cfu} / \mathrm{ml}$ SP007s concentrations for seed treatment and foliar spray as effective as economic threshold of SP007s utilization were recommended (Chuaboon and Prathuangwong, 2007).

Previous research showed that an 18-month-old ISR- 
$\mathrm{P}^{\circledR}$ formulation with less than $53.8 \%$ of the original concentration of the biocontrol agent SP007s still provided effective control of various diseases (Prathuangwong, 2009). In this study, the loss of microbial viability during storage is one of the most important problems for microbial strains that do not form spores and formulation ingredients can improve storage survival (Siripornvisal and Trilux, 2011). In the dose of SP007s, use of kaolin allowed significantly better survival and storage stability than talc. The higher number of SP007s population in kaolin-based formulation might be due to their unique organic nature and other physio-chemical properties (Siripornvisal and Trilux, 2011). The optimal survival environment in formulation includes many variables such as temperature, moisture content, substrate (inert support and nutrients), and long term storage.

The solid substrate acts as a heterogenous source of carbon, nitrogen and minerals as well as growth factors including an ability to absorb water (Bharathi et al., 2004). Water is necessary to facilitate utilization of the nutrient substrates by the biocontrol agents. However, water excesses cause substrates to be sticky, limiting oxygen transfer and increasing the risk of saprophyte contamination; whereas, in very low moisture level, no growth of microorganism will be evident (Preecha and Prathuangwong, 2009). Although, SP007s reduced the disease incidence overall treatments, reduction of dirty panicle disease was greatest only by talc-based formulation treated plants. Similar good levels of disease control by $P$. fluorescens SP007s in field trials have been demonstrated in other economic crops (Chuaboon et al., 2009; Prathuangwong et al., 2009). These research works provided 12.4 to $49.6 \%$ control of several diseases in various crops when applied with the biocontrol agent $P$. fluorescens SP007s.

The cfu recovery of SP007s from field trial after foliar spray application demonstrated that the strain was established at stable levels in the rice phyllosphere after its initial introduction (data not shown). It could be recovered in high number $\left(10^{6}\right.$ to $\left.10^{9} \mathrm{cfu} / \mathrm{ml}\right)$ over a period of time known to be critical for attack by dirty panicle pathogens, suggesting 6-time foliar sprays conducted in this study may be sufficient for controlling the disease.

However, application time of biocontrol agent was critical with respect to susceptible growth stage of plant for pathogen infection. The disease was severe attack at panicle stage (70 to 98 -day-old plants) that no spray was recommended, frequency spray before or 1 to 2 sprays at panicle stage with SP007s bioproduct should be conducted for most effective management strategy. Recent investigation on mechanism of biocontrol by SP007s revealed that it protects plants from pathogen attack by induced different defense enzymes increased accumulation in treated plants (Prathuangwong and Buensanteai, 2007). Some of these enzymes involved in synthesis of phytoalexins and pathogenesis-related proteins that highly toxic to pathogens in different mechanisms (Cohen et al., 1994; Ramputh and Bown, 1996; Prathuangwong and Buensanteai, 2007; Buensanteai et al., 2009). Plant growth by PGPR strains include the bacterial synthesis of plant hormone indole-3-acetic acid or IAA (Buensanteai et al., 2008), cytokinin and gibberellins (Prathuangwong, 2009) that might account for plant growth promoting by PGPR-SP007s in this study.

These Pseudomonas bioformulations produced multiple effects, are easy to use and, most importantly, they are chemical-free (Raj et al., 2003). However, costeffectiveness has to be worked out and if found feasible then these plant growth promoting rhizobacteria bioformulations may effectively integrate into a rice diseases control program in the near future.

Futuremore, for the future research, the effect of polymeric additives, adjuvants, surfactants on survival, stability and plant growth promoting ability of liquid bioinoculants will be performed.

\section{ACKNOWLEDGEMENTS}

This research was supported by Office of the National Research Council of Thailand under 2-V Research Program and Center for Advanced Studies in Tropical Natural Resources, Kasetsart University that have been granted by Office of the Higher Education Commission, Thailand. We thank Dr. Warunee Varanyanond and her lab members at Institute of Food Research and Product Development, Kasetsart University for kind support and technical assistance in detecting GABA accumulation.

\section{REFERENCES}

Amran M (2006). Biomass production and formulation Bacillus subtilis for biological control. Inidonesian J. Agri. Sci. 7(2):51-56.

Anitha A, Rabeeth M (2009). Control of fusarium wilt of tomato by bioformulation of Streptomyces griseus in green house condition. Afr. J. Basic Appl. Sci. 1(1-2):9-14.

Ardakani SS, Heydari A, Khorasani N, Arjmandi R (2010). Development of new bioformulations of Pseudomonas fluorescens and evaluation of these products against damping-off cotton seedlings. J. Plant Pathol. 92(1):83-88.

Ardakani SS, Heydari A, Tayebi L, Cheraghi M (2011). Evaluation of efficacy of new bioformulations on promotion of cotton seedlings. Environ. Sci. Technol. 6:361-364.

Bharathi R, Vivekananthan R, Harish S, Ramanathan A, Samiyappan R (2004). Rhizobacteria-based bio-formulations for the management of fruit rot infection in chillies. Crop Protection 23:835-843.

Bradford MM (1976). A rapid and sensitive method for the quantification of microgram quantities of protein utilizing the principle of protein-dye binding. Anal. Biochem. 72:248-254.

Buensanteai N, Yuen GY, Prathuangwong S (2008). The biocontrol bacterium Bacillus amyloliquefaciens KPS46 produces auxin, surfactin and extracellular proteins for enhanced growth of soybean plant. Thai J. Agri. Sci. 41(3):101-116.

Department of Agriculture (2011). Available source at: www.doa.go.th/human/other_49/ produce_49.pdf. Accessed20 September 2011. 
Buensanteai N, Yuen GY, Prathuangwong S (2009). Priming, signaling, and protein productivity associated with induced resistance by Bacillus amyloliquefaciens KPS46. World J. Biotechnol. 25:12751286.

Chaluvaraju G, Basavaraju P, Shetty NP, Deepak SA, Amruthesh KN, Shetty HS (2004). Effect of some phosphorous-based compounds on control of pearl millet downy mildew disease. Crop Protection 23:595600.

Chen XH, Scholz R, Borriss M, Junge H, MÖgel G, Kunz S, Borriss R (2009). Difficidin and bacilysin produced by plant-associated Bacillus amyloliquefaciens are efficient in controlling fire blight disease. J. Biotech. 140(1-2):38-44.

Chuaboon W, Prathuangwong S (2007). Biological control of cauliflower soft rot using bacterial antagonist and its risk assessment. J. Thai Phytopathol. 21:63-48.

Chuaboon W, Thein A, Nurapak S, Prathuangwong S (2009). Biological analysis of Pseudomonas fluorescens SP007s induced systemic resistance in sweet corn against bacterial leaf streak. In: Proceedings of the $1^{\text {st }}$ Int. Conf. on Corn and Sorghum Research, Apr 8-10, 2009, Chonburi, pp. 206-215.

Cohen Y, Niderman T, Mosinger E, Fluhr R (1994). $\beta$-Aminobutyric acid induces the accumulation of pathogenesis-related proteins in tomato (Lycopersicon esculentum L.) plants and resistance to late blight infection caused by Phytophthora infestans. Plant Physiol. 104: 59-66.

Commare RR, Nandakumar R, Kandan A, Suresh S, Bharathi M, Raguchander T, Samiyappan R (2002). Pseudomonas fluorescens based bio-formulation for the management of sheath blight disease and leaffolder insect in rice. Crop Protection 21:671-677.

Cook RJ (2002). Advances in plant health management in the twentieth century. Annu. Rev. Phytopathol. 38:95-116.

Dhindsa R, Plum-Dhindsa P, Thorpe TA (1981). Leaf senescence: Correlated with increased levels of membrane permeability and lipid peroxidation and decreased levels of superoxide dismutase and catalase. J. Exp. Bot. 32(1):93-101.

Erlander MG, Tobin AJ (1991). The structural and functional heterogeneity of glutamic acid decarboxylase: A review. Neurochem. Res. 16(3):215-226.

Haggag M, Wafaa SS (2012). Development and production of formulations of PGPR cells for control of leather fruit rot disease of strawberry. Am. J. Sci. Res. 67:16-22.

Hammerschmidt R, Lamport DTA, Muldoon EP (1984). Cell wall hydroxyproline enhancement and lignin deposition as an early event in the resistance of cucumber to Cladosporium cucumerinum. Physiol. Plant Pathol. 24:43-47.

Levesque $R$ (2007). SPSS programming and data management: A guide for SPSS and SAS users, $4^{\text {th }}$ ed. SPSS Inc., Chicago.

Ling V, Snedden WA, Shelp BJ, Assmann SM (1994). Analysis of a soluble calmodulin binding protein from fava bean roots: Identification of glutamate decarboxylase as a calmodulin-activated enzyme. Plant Cell 6:1135-1143.

Ming Z, Ma Y, Wei Z (2011). Determination and comparison of $\mathrm{Y}^{-}$ aminobutyric acid (GABA) content in Pu-erh and other types of Chinese tea. J. Agric. Food Chem. 59(8):3641-3648.

Nurapak S, Prathuangwong S (2010). Culture media for increased antimicrobial activity of mixed bacterial antagonists. In: Proceedings of $49^{\text {th }}$ Kasetsart Uni. Annu. Conf., Feb 1-4, Bangkok, pp. 131-140.

Omer MA (2010). Bioformulations of Bacillus spores for using as Biofertilizer. Life Sci. J. 7:4.

Pan SQ, Ye XS, Kuc J (1991). Association of $\beta$-1,3-glucanase activity and isoform pattern with systemic resistance to blue mould in tobacco induced by stem injection with Peronospora tabacina or leaf inoculation with tobacco mosaic virus. Physiol. Mol. Plant Pathol. 39: 25-39.

Prathuangwong S, Chuaboon W, Kasem S, Hiromitsu N, Suyama K (2007). Formulation development of Pseudomonas fluorescens SP007s to control Chinese kale diseases in farming production. Abstract of paper. In: Proceedings of the ISSAAS Int. Cong. Agriculture Is a Business, Dec $12-14$, Melaka, p. 58.
Prathuangwong, S, Pornprom T, Kasem S, Thowthampitak J, Chuaboon W (2008). Integrated pest management of sustainable rice production. A Research Report, Office of the Higher Education Commission, Bangkok.

Prathuangwong S (2009). Biological control of brassicaceae diseases using the new bacterial antagonist strains. The 5-Year AFRP Project Report 2004-2008. Tokyo University of Agriculture, Tokyo.

Prathuangwong S, Chuaboon W, Kasem S, Athinuwat D, Suyama K, Negishi H (2009). Potential for application time of Pseudomonas fluorescens SP007s and biofertilizer for Alternaria leaf spot management of Chinese kale. Abstract of paper. In: Proceedings of the ISSAAS Int. Conf., Feb 23-27, Bangkok, p. 81.

Preecha C, Prathuangwong S (2009). Development of Bacillus amyloliquefaciens KPS46 formulation for control of soybean disease. Abstract of paper. In: Proceedings of the ISSAAS Int. Conf., Feb 2327, Bangkok, p. 222.

Pushpalatha HG, Mythrashree SR, Shetty R, Geetha NP, Sharathchandra RG, Amruthesh KN, Shetty SH (2007). Ability of vitamins to induce downy mildew disease resistance and growth promotion in pearl millet. Crop Protection 26:1674-1681.

Ramputh Al, Bown AW (1996). Rapid [gamma]-aminobutyric acid synthesis and the inhibition of the growth and development of oblique-banded leaf-roller larvae. Plant Physiol. 111(4):1349-1352.

Raj NS, Deepak SA, Basavaraju P, Shetty HS, Reddy MS, Kloepper WJ (2003). Comparative performance of formulations of plant growth promoting rhizobacteria in growth promotion and suppression of downy mildew in pearl millet. Crop Protection 22:579-588.

Schisler DA, Slininger PJ, Behle RW, Jackson MA (2004). Formulation of Bacillus spp. for biological control of plant diseases. Phytopathology 94 (11):1267-1271.

Sharathchandra RG, Raj NS, Shetty NP, Amruthesh KN, Shetty SH (2004). A Chitosan formulation Elexat induces downy mildew disease resistance and growth promotion in pearl millet. Crop Protection 23: 881-888.

Senthilraja G, Anand T, Durairaj C, Raguchander T, Samiyappan R (2010). Chitin-based bioformulation of Beauveria bassiana and Pseudomonas fluorescens for improved control of leaf minor and collar rot in groundnut. Crop Protection 29:1003-1010.

Siripornvisal S, Trilux S (2011). Effect of a bioformulation containing Bacillus subtilis BCB3-19 on early growth of hongtae pak choi. Agri. Sci. J. 42(2):293-296.

Upadhyaya A, Ankhla D, Davis N, Sankhla N, Smith BN (1985). Effect of paclobutrazol on the activities of some enzymes of activated oxygen metabolism and lipid peroxidation in senescing soybean leaves. J. Plant Physiol. 121:453-461.

Van Loon LC, Bakker PA, Pieterse CM (1998). Systemic resistance induced by rhizosphere bacteria. Annu. Rev. Phytopathol. 36:453483 